\title{
SOBRE A CRIMINALIZAÇÃO DA "VIOLAÇÃO DE PRERROGATIVAS DO ADVOGADO”: PALEORREPRESSÃO DE SENTIDO IMPRÓPRIO
}

ON THE CRIMINALIZATION OF THE VIOLATION OF ATTORNEYS' PREROGATIVES: PALEOREPRESSION OF IMPROPER MEANING

\author{
Saulo Tarcisio de Carvalho Fontes* \\ Guilherme Guimarães Feliciano**
}

\begin{abstract}
Resumo:
Projetos de Lei n. 4.915 e n. 5.762, ambos de 2005 (Câmara dos Deputados), e PLC n. 83, de 2008 (Senado Federal), que "define o crime de violação de direitos e prerrogativas do advogado". Inconstitucionalidade e inconveniência políticolegislativa. Inconstitucionalidade por estatuir tipo penal incriminador alheio ao Programa Penal da Constituição. Inconstitucionalidade por configurar "tipo penal aberto", violando o direito fundamental à garantia da reserva legal. Possibilidade de conflito ou colisão com imunidade de magistrados, membros do Ministério Público, parlamentares e até mesmo de advogados, no exercício das respectivas funções. Possibilidade de criminalização de convicção de magistrado, membro do Ministério Público e Parlamentares (CPI's), criando hipótese de "crime de hermenêutica". Inconveniência da política generalizada de criminalização de condutas banais. Violação do Princípio da Intervenção Mínima. Intimidação concreta das autoridades públicas na atuação de combate ao crime organizado, funcionando como "peia" inibitória nas medidas judiciais de produção de provas. Excessos recentes da Ordem dos Advogados do Brasil (seções estaduais), a tisnar o nome e a imagem de autoridades e cidadãos diversos, em circunstâncias tais que, a vingar o teor do PL n. 4.915/2004, teriam, na ótica daquela ordem profissional, configurado "crimes". Risco sério de perseguições corporativas. Suficiência da legislação penal em vigor para repelir condutas abusivas ou desproporcionais de magistrados e membros do Ministério Público.

Palavras-Chave: Violação de prerrogativas. Tipo penal aberto. Princípio da taxatividade. Programa Penal da Constituição. Ações corporativas.
\end{abstract}

\begin{abstract}
:
Law Drafts 4,915 and 5,762, both issued in 2005 (House of Representatives), and Law Draft 83, issued in 2008 (Federal Senate), which define the crime of violation
\end{abstract}

\footnotetext{
Juiz do Trabalho Titular da $2^{\text {a }}$ Vara do Trabalho de São Luís do Maranhão, é Doutor em Direito pela Faculdade de Direito da Universidade Federal de Pernambuco e Membro da Comissão Legislativa da Associação Nacional dos Magistrados da Justiça do Trabalho Anamatra.

** Juiz do Trabalho Titular da $1^{\text {a }}$ Vara do Trabalho de Taubaté/SP, é Livre Docente em Direito do Trabalho e Doutor em Direito Penal pela Faculdade de Direito da Universidade de São Paulo. Doutorando em Ciências Jurídicas pela Faculdade de Direito da Universidade de Lisboa. Extensão Universitária em Economia Social e do Trabalho (Universidade Estadual de Campinas - Unicamp). Professor Assistente Doutor do Departamento de Ciências Jurídicas da Universidade de Taubaté e Coordenador do Curso de Especialização Lato Sensu em Direito e Processo do Trabalho na mesma Universidade. Professor Assistente do Curso de Especialização Lato Sensu em Direito Processual Civil (2006-2007) e em Direito Civil (2008-2009) da Escola Paulista da Magistratura (EPM/APAMAGIS). Secretário Geral da Amatra-XV (Associação dos Magistrados do Trabalho da Décima Quinta Região), gestão 2007-2009.
} 
of rights and prerogatives of attorneys. Unconstitutionality and political, legal inconvenience. Unconstitutionality by defining a criminal type alien to Constitutional Criminal Program. Unconstitutionality for being a "open-type" crime, which violates the fundamental right to the legal reserve guarantee. Possibility of conflict or collision with immunity of judges, public prosecutors, representatives and even attorneys in the exercise of their respective functions. Possibility of criminalization the conviction of judges, public prosecutors and representatives in Parliament Commissions for Investigations, creating a hypothesis of "crime of hermeneutics". Inconvenience of the general policy of irrelevant conducts criminalization. Violation of the principle of minimal intervention. Actual intimidation of public authorities in the combat of organized crime, serving as inhibitory restraint in judicial measures of evidences formation. Recent abuses of the Brazilian Bar Association (State Sections), to blacken the name and image of authorities and citizens, configuring as "crimes". Major risks to corporation prosecutions. Sufficiency of criminal laws in force to repeal abusive or disproportional conducts of judges and public prosecutors.

Keywords: Violation of Prerogatives. Open-Type Crime. Principle of Taxativity. Constitutional Criminal Program. Corporative attacks.

\section{Introdução}

Em meados de 2007, a Associação Nacional dos Magistrados do Trabalho - Anamatra, entidade da sociedade civil representativa dos Juizes do Trabalho do Brasil, solicitou à sua Comissão Legislativa uma nota técnica a respeito do então Projeto de Lei n. 4.915/2004 (Câmara dos Deputados), atual PLC n. 83/2008 (Senado Federal), e demais a este apensados, todos tendentes à tipificação formal do crime de violação das prerrogativas de advogados. A nota técnica então produzida foi manifestamente contrária àquela proposição legislativa, pelas razões expostas no corpo deste trabalho.

Nada obstante, o projeto de lei terminou aprovado pelo plenário da Câmara dos Deputados, seguindo para a regular tramitação no Senado Federal, aos cuidados do senador Demóstenes Torres, ainda no âmbito da Comissão de Constituição e Justiça daquele órgão. A essa altura, a Comissão Legislativa da Anamatra produziu uma segunda nota técnica, agregando ao texto original da lavra do juiz Saulo Fontes as ponderações do juiz Guilherme G. Feliciano, convidado especialmente para esse fim.

Outra vez, a nota encaminhou parecer contrário à aprovação do PLC n. 83/2008, apesar de suas melhorias em relação aos projetos oriundos da Câmara dos Deputados (entre outras coisas, a redação apresentada ao Senado Federal fechou melhor o tipo penal). Nada obstante, pugnou-se outra vez pela sua rejeição, por se entender, entre outras coisas, que (a) o texto proposto prossegue violando o princípio da reserva legal e o programa penal da Constituição da República Federativa do Brasil; (b) abre ensanchas a condenações por "crime de hermenêutica"; (c) inibe, no limite, a atuação dos agentes do 
Estado no combate ao crime organizado; e (d) conflita com a imunidade constitucional dos magistrados, membros do Ministério Público, advogados e parlamentares.

Para mais, compreendeu-se que o PLC n. 83/2008, uma vez aprovado, poderia ser instrumentalizado para abordagens institucionais mais agressivas das seções estaduais da Ordem dos Advogados do Brasil, refratárias às liberdades constitucionais, a exemplo do que já vem ocorrendo em alguns Estados, ao sabor de julgamentos ou perseguições puramente corporativas, vilipendiando a tessitura básica do Estado Democrático de Direito. O projeto de lei pecaria, ainda, pelo excesso, uma vez que as leis penais em vigor — em especial o Código Penal, com seus arts. 322 e 350, e a própria Lei n. 4.898/65 - já seriam suficientemente severas no tratamento de juízes, promotores, procuradores e delegados (entre outras autoridades) que desbordassem de seus deveres funcionais e violassem prerrogativas de outros profissionais.

Com tais conteúdos, a segunda nota técnica vem sendo encaminhada a todos os senadores da República, com o objetivo precípuo de esclarecê-los, mais que dissuadilos. Pareceu-nos, todavia, que a discussão circunscrevia-se a um número muito limitado de interlocutores (basicamente parlamentares, ao lado de um restrito grupo de juízes e advogados). Discussão dessa monta, com conseqüências tão emblemáticas para o tecido social brasileiro, haveria de ser aberta ao grande público, sobretudo aos operadores do Direito que, na militância do dia-a-dia, não estão vinculados aos quadros diretivos da $\mathrm{OAB}$ e tampouco às associações de magistrados, de membros do Ministério Público e de delegados de Polícia. E, é claro, ao cidadão comum.

Daí a idéia e a finalidade primeira do presente artigo, que reproduz basicamente os argumentos esgrimidos na segunda nota técnica da Comissão Legislativa da Anamatra. Ao leitor, não se pede mais que desassombro e isenção de ânimos na ponderação das razões aqui desfiladas. Nosso escopo não é, em absoluto, forçar à assimilação de idéias. É tão-só apresentá-las, tal como urdidas, para a sua reflexão. Voilà.

2. Do teor da alteração legislativa proposta

Ao tempo do primeiro projeto, do deputado Marcelo Barbieri, o que se propunha essencialmente era a inserção, no ordenamento jurídico pátrio, de dispositivo legal que estabeleceria, na versão original, o seguinte:

Constitui crime violar direito ou prerrogativa do advogado impedindo a sua atuação profissional.

Pois bem. Aprovado recentemente pela Câmara dos Deputados, o PL n. 5.762/2005 recebeu, no Senado Federal, o n. 83/2008, agora tramitando com a seguinte redação (por aditamento ao teor da Lei Federal n. 8.906/1994 - Estatuto da Advocacia): 
Art. 7-A. Violar direito ou prerrogativa do advogado, estabelecido no artigo $7^{\circ}$ desta Lei, impedindo ou limitando sua atuação profissional, prejudicando interesse legitimamente patrocinado:

Pena - detenção, de 6 (seis) meses a 2 (dois) anos, sem prejuízo da pena correspondente à violência, se houver.

Observe-se que o dispositivo a ser inserido no ordenamento jurídico não textualiza a relação dos direitos e prerrogativas que, uma vez violados, geraria a incidência do tipo penal. Faz apenas remissão ao art. $7^{\circ}$ do Estatuto da Advocacia, que possui preceitos tão genéricos quanto "exercer, com liberdade, a profissão em todo o território nacional" (inciso I), ou tão anódinos como "permanecer sentado ou em pé e retirar-se de quaisquer locais indicados no inciso anterior" (inciso VII, reportando-se às salas de sessões, audiências, cartórios, etc.). A rigor e em tese, aprovada a lei, poderiam configurar o crime condutas tão isentas e corriqueiras como o bloqueio temporário de passagem do veículo de um advogado em blitze policiais ou a ausência de cadeiras em sala de audiência para que o causídico pudesse se acomodar.

Com efeito, a conduta sobre a qual incidiria a pena seria, na redação original, "complementada" por todos os dispositivos do ordenamento jurídico que estabelecem, de qualquer modo, direito e prerrogativa de advogados, bem como, para o futuro, por toda alteração legislativa que viesse a modificar os dispositivos atinentes a direitos e prerrogativas já existentes, ou que criassem novos direitos e prerrogativas. Já na nova redação (PLC n. 83/2008), o "complemento" ater-se-ia ao art. $7^{\circ}$ (conquanto seja possível, em tese, argumentação tendente à interpretação extensiva ou analógica, que se admite em Direito Penal, inclusive "in pejus"; veja-se, e.g. e respectivamente, o caso do crime de bigamia, que também alcança as hipóteses de poligamia, e o caso das cláusulas gerais definidoras do homicídio qualificado). Trata-se, em todo caso, de norma penal em branco que - vê-se desde logo - tisna irreversivelmente o princípio da taxatividade penal, corolário da legalidade penal estrita. E nisso anda mal, como se verá (tópico n. 3).

Iniludível, portanto, que a imensidão da abrangência do tipo penal geraria, “a se”, intensa insegurança jurídica, além da inibição de atuação dos agentes do Estado, ainda que dentro do espaço legal e constitucional de sua atuação.

No sistema jurídico vigente, como visto, a maior parte da "complementação" do tipo penal estaria na Lei n. 8.906 de 1994, especialmente nos seus arts. $6^{\circ}$ e $7^{\circ}$. Com a nova redação (PLC n. 83/2008), tal "complementação" ater-se-ia ao art. $7^{\circ}$. Atenua-se o defeito; mas não se redime a inconstitucionalidade.

A amplitude desta tipificação pode ser percebida logo à primeira vista, considerando a grande relação de direitos e prerrogativas previstos nos mencionados artigos. Daí o possível cerceamento à própria liberdade de condução do processo que é assegurada aos juízes, a teor do art. 445, I a III, do CPC, ou aos próprios parlamentares, 
nos ensejos do art. 58, $\S 3^{\circ}$, da CRFB. Assim, p.ex., entrever-se-ia crime na mais banal discussão sobre o acesso do advogado a uma área onde é realizada a sessão de Tribunal, ou ainda - e inclusive - em decorrência das interpretações possíveis quanto à participação do advogado em Comissões Parlamentares de Inquérito, não-só quanto ao direito de acompanhar-lhe as diversas fases, mas também quanto à oportunidade de assento e voz.

Do mesmo modo, poder-se-ia chegar ao extremo de se enfrentar um processo criminal pela conduta de "não-recebimento do advogado", seja pelo juiz, pelo promotor ou mesmo pelo parlamentar, quando atuar em CPI's em situações análogas... Nestes casos, não raramente, surgem controvérsias quanto à existência de compromissos concomitantes, a par de outros tantos contextos de exigências não-razoáveis por parte de advogados. Caso a autoridade não ceda aos argumentos do causídico e termine por não o receber naquele dia, haverá crime? Afinal, parecerá tisnado um dos incisos do art. $7^{\circ}$ do Estatuto da Advocacia...

Ainda em tese, por interpretação extensiva (que, diga-se novamente, é admitida em Direito Penal), exsurgiriam processos criminais a discutir se o servidor, o magistrado e/ou outros quaisquer - a rigor, qualquer cidadão - teria $(\mathrm{m})$ dispensado ao advogado o tratamento cortês previsto no parágrafo único do art. $6^{\circ}$ do Estatuto da Advocacia, ao dispor que "as autoridades, os servidores públicos e os serventuários da justiça devem dispensar ao advogado, no exercício da profissão, tratamento compativel com a dignidade da advocacia e condições adequadas a seu desempenho". Ter-se-ia, mesmo, o "crime de destempero" (o que faz recordar ação movida por juiz fluminense que desejava ser chamado pelo vocativo "senhor" ou "doutor", nas dependências do condomínio horizontal em que vivia, a cuja pretensão não acederam as associações de classe da Magistratura...). Qual seria o limite deste tipo penal?

Por outro lado, porque o art. 22 da Lei n. 8.906/94 inclui os honorários advocatícios no rol de direitos dos advogados, interpretações extensivas poderiam engendrar discussões sobre a tipicidade da conduta de um ou outro advogado, no rateio ou partilha de honorários; ou, bem assim, sobre a tipicidade da conduta do cliente ou até do juiz que, sobre o direito aos honorários contratuais e de sucumbência, delibere contra os interesses de certo advogado. Também esses - o juiz, o cliente e/ou o próprio colega de profissão - incorreriam em crime de "violação de prerrogativas"... Nada mais absurdo.

Poderíamos ter ainda, como conduta criminosa de violação de direito do advogado, a omissão do empregador no cumprimento dos direitos trabalhistas, pagamento de horas extras, percentual de honorários de sucumbência, dentre outros, podendo o indivíduo sujeito ao processo-crime ser o próprio representante do empregador, inclusive em sociedade de advogados. 
O que se pretende demonstrar com essa extensa casuística é que, concretamente, o tipo é absolutamente genérico e impraticável, sendo por isso inconstitucional, como também inconveniente a sua inserção no ordenamento jurídico.

Mas não é só.

3. O princípio da reserva legal previsto no art. 5, XXXIX, da Constituição Federal, a taxatividade penal e a vedação dos tipos penais excessivamente abertos

$\mathrm{O}$ inciso XXXIX do art. $5^{\circ}$. da $\mathrm{CF} / 88$ consagra a garantia fundamental e o princípio universal da reserva legal, ao determinar que "não há crime sem lei anterior que o defina, nem pena sem prévia cominação legal".

Como corolário deste princípio, desenvolveu-se o subprincípio da máxima taxatividade penal (supra). Por ele, estão constitucionalmente vedados tipos penais excessivamente abertos e genéricos.

Segundo Paulo de Souza Queiroz, ${ }^{1}$

O princípio da reserva legal implica a máxima determinação e taxatividade dos tipos penais, impondo-se ao Poder Legislativo, na elaboração das leis, que redija tipos penais com a máxima precisão de seus elementos, bem como ao judiciário que as interprete restritivamente, de modo a preservar a efetividade do princípio.

Com efeito, a garantia de que não haverá crime ou pena sem lei anterior que os defina restaria absolutamente inócua se fosse admitida a tipificação genérica de conduta que pudesse ser enquadrada como crime ou mesmo servir de agravante da pena.

À guisa de exemplos, não se poderiam criminalizar condutas genéricas como "mau procedimento" (previsto na CLT), "falta de urbanidade" (previsto na Lei n. 8.112/90) ou - como já se fez o Brasil, ao tempo do antigo Código de Pesca - "molestamento de cetáceos" (tipo penal que, por isso mesmo, jamais foi aplicado pelo Poder Judiciário brasileiro). Na mesma linha, não se podem criminalizar condutas genéricas e desprovidas de conteúdo seguro como, p.ex., "tratamento incompatível com a dignidade do advogado" e "não concessão das condições adequadas ao desempenho da advocacia". Estes dois últimos exemplos estariam entre aqueles que, justamente, configurariam o novel crime "violação de direitos e prerrogativas de advogado", caso aprovado o projeto de lei mencionado.

Para ilustrar tipo penal excessivamente aberto, a doutrina nacional sempre fez referência ao art. 15 da Lei de Segurança Nacional, que criminalizava "atos de sabotagem", entendendo que esta expressão envolvia conduta por demais genéricas. Pois bem: pode-

1 QUEIROZ, Paulo de Souza. Direito Penal: Introdução crítica. São Paulo: Saraiva, 2001. p. 23-24. 
se certamente afirmar que tal expressão é mais precisa do que a indefectível "violação de direito ou prerrogativa do advogado, [...] impedindo ou dificultando sua atuação profissional". Seria algo como criminalizar a "violação das prerrogativas do magistrado, impedindo ou dificultando o exercício e a eficácia da jurisdição" (que, a valer a tese político-legislativa, teria igual valor republicano): configurado esse tipo penal, poderiam responder pelo "crime" tantos quantos fossem advogados e interpusessem embargos de declaração protelatórios... Por essa alheta, percebe-se o insólito da proposição.

Ao mais, para que dúvidas não pairem quanto à inconstitucionalidade do dispositivo, deve ser observada a sua natureza própria de norma penal em branco (supra) e, bem assim, os limites dessa natureza. Assim, e.g., na criminalização de tráfico ilícito de entorpecentes, opera-se bem com o tipo aberto por remissão legislativa: se a lei não descreve quais substâncias sejam «drogas» na dicção da Lei n. 11.343/2006 ou entorpecentes e substâncias que causam dependência física ou psíquica na dicção da revogada Lei n. 6.368/76, porque hão de fazê-lo as portarias do Ministério da Saúde e das agências correlatas (como faziam, outrora, as portarias do DIMED), é certo que o texto legal criminaliza essencialmente a conduta de portar as substâncias proibidas. A conduta, em si, é certa; a relativa abertura atrela-se tão-só ao objeto técnico-material do delito. E mesmo estas leis têm sofrido sérias críticas e restrições na seara do Direito Penal. Ademais, não é dessa espécie e hipótese em testilha. No caso presente, a proposta é de dispositivo aberto que se refere a um «status» jurídico já previsto em lei, que, por sua vez, conduz a situações concretas ainda mais abertas.

Como se vê facilmente pelos exemplos concretos indicados há pouco, ao se criminalizar genericamente a conduta de "violação de direitos e prerrogativas de advogado", com remissão a legislação que define direitos e prerrogativas (em especial o art. $7^{\circ}$ da Lei n. 8.906/94), estar-se-ia criando uma norma inconstitucional, tendo em vista os vários direitos e prerrogativas dos advogados, descritos em lei de modo inteiramente aberto, com níveis de insegurança jurídica dificilmente assimiláveis pelo Estado de Direito ou pelo principio da reserva legal.

A esse propósito, veja-se, ademais, o escólio de Zaffaroni e Batista: ${ }^{2}$ ...não basta que a criminalização primária se formalize em uma lei, mas sim que ela seja feita de uma maneira taxativa e com a maior precisão técnica possível, conforme ao princípio da máxima taxatividade...

Vejam-se, outrossim, as lições do espanhol Rodriguez-Arias, para quem o princípio da reserva legal só não é ferido pela norma penal em branco por um imperativo

2 ZAFFARONI, Eugénio Raul; BATISTA, Nilo. Direito penal brasileiro. 2. ed. Rio de Janeiro: Revan, 2003. v. 1. 
pragmático: a legalidade penal, ainda se qualificada de absoluta, não pode ser entendida em termos tão estritos que obstem às disposições jurídicas de categoria inferior o papel de complementar tecnicamente a lei penal. Do contrário, haveria de se conferir à norma penal, que deve ser clara por excelência, um nível de complexidade absolutamente impróprio nas matérias mais técnicas, com prejuízo para a segurança jurídica. Mas a questão que se põe é, sempre, a dos limites da delegação normativa: há que se fixar os limites de admissibilidade da remissão ou reenvio, para que não se promova uma autêntica deslegalização ("deslegalización”) de matérias reservadas ao império da lei. Assim, o mecanismo de reenvio normativo - como ocorre nos delitos de tráfico de drogas - deve cumprir um papel exclusivamente técnico, de enunciação e atualização dos fatos que a lei indica como merecedores de sanção pelo desvalor que encerra. ${ }^{3}$ À normativa administrativa cabe o enunciado da norma técnica; à lei, o enunciado da norma jurídica. Nesse encalço, a descrição administrativa acaba por aumentar o grau de segurança jurídica da norma penal, atendendo à taxatividade da lei penal e limitando o espaço de ação da jurisprudência. A não ser assim, a tipificação remissiva carece de determinação e se presta a arbitrariedades, alijando do tipo penal o seu escopo de clareza e a sua função de certeza. ${ }^{4}$ É precisamente o caso em comento. Logo, não há dúvidas de que o dispositivo, uma vez inserido no ordenamento jurídico pátrio, ostentará ab ovo a eiva da inconstitucionalidade.

4. Inconstitucionalidade. Previsão típico-penal alheia ao programa penal da Constituição Federal de 1988

Bem se sabe que o Direito Penal deve ter natureza fragmentária. Isso é mais verdadeiro quanto se vive sob a égide de um Estado Democrático de Direito, como é o caso. Logo, o legislador infraconstitucional não pode, ao seu inteiro talante, "decidir" o que deva ou-não ser criminalizado no Brasil. Não se poderia, p.ex., "criminalizar" a conduta consistente em praticar tal ou qual ato libidinoso, quando os parceiros, maiores e capazes, deliberam consensualmente praticá-lo. Tampouco se poderia “criminalizar" o ato de pertencer a tal ou qual torcida uniformizada. Nem mesmo se pode criminalizar, no Brasil, o próprio incesto, se consentido por pessoas maiores, livres e capazes. Isso porque todos esses aspectos, se têm relevância na perspectiva ético-social ou sociocultural, são irrelevantes do ponto de vista constitucional, notadamente à mercê da primazia das liberdades na Carta de 1988.

3 RODRÍGUEZ-ARIAS, Antonio Mateos. Derecho penal y protección del medio ambiente. Madrid: Colex, 1995. p. 159-163. Cfr. ainda, no mesmo sentido, FELICIANO, Guilherme Guimarães. Teoria da imputação objetiva no Direito Penal ambiental. São Paulo: LTr, 2005. p. 445-450.

4 Id. Ibid., p.164-166. 
Dito de outro modo, há um programa penal constitucional ínsito à Constituição da República Federativa do Brasil, ao qual deve se ater o legislador ordinário. Nem todas as condutas sociais são passíveis de criminalização, ao bel-prazer do legislador; há, também aqui, limites mais ou menos claros. Só se podem criminalizar condutas que lesem ou ameacem de lesão bens jurídicos com estrito status constitucional (vida, honra, liberdade, propriedade, segurança coletiva, probidade administrativa, etc.); outros aspectos, sem explícita dimensão tuitivo-constitucional (como, p.ex., orientações sexuais ou político-ideológicas, tradições culturais, meras prerrogativas profissionais, etc.), não admitem criminalização em tese.

Nesse diapasão, lê-se, em Claus Roxin, que

El punto de partida correcto consiste en reconocer que la única restricción previamente dada para el legislador se encuentra en los principios de la Constitución. Por tanto, un concepto de bien jurídico vinculante políticocriminalmente sólo se puede derivar de los cometidos, plasmados en la Ley Fundamental, de nuestro Estado de Derecho basado en la libertad del individuo, a través de los cuales se le marcan sus límites a la potestad punitiva del Estado. En consecuencia se puede decir: los bienes jurídicos son circunstancias dadas o finalidades que son útiles para el individuo y su libre desarrollo en el marco de un sistema social global estructurado sobre la base de esa concepción de los fines o para el funcionamiento del propio sistema. [...] De tal concepto de bien jurídico, que le viene previamente dado al legislador penal, pero no es previo a la Constitución, se pueden derivar una serie de tesis concretas. ${ }^{5}$

Roxin segue apresentando as teses concretas derivadas da estrita vinculação do bem jurídico-penal face à Constituição, pontuando que não podem ser objeto do Direito Penal, por implícita vedação constitucional, (a) as cominações penais arbitrárias (como, e.g., exigir que os cidadãos tributem reverência a um símbolo qualquer); (b) as meras imoralidades (como, e.g., práticas sexuais atípicas, desde que consentidas entre pessoas maiores, livres e capazes); (c) as finalidades puramente ideológicas (como lamentavelmente houve, ao tempo da Alemanha nazista, com vistas a tutelar a "manutenção da pureza do sangue alemão"); e (d) os preceitos penais que criam ou asseguraram desigualdades entre iguais. ${ }^{6}$

Nessa linha, pode-se reconhecer a inconstitucionalidade do PLC n. 83/2008 ao menos por dois motivos:

\footnotetext{
5 ROXIN, Claus. Derecho Penal: parte general (Fundamentos. La estructura de la teoria del delito). Trad. Diego-Manuel Luzón Peña, Javier de Vicente Remesal. Madrid: Civitas, 1997. t. I. pp.51-58 ("La derivación del bien jurídico de la Constitución" - g.n.).

6 Id. Ibid., p. 56-57.
} 
(i) criminalizar-se-á onde, a rigor, não se pode criminalizar, pois as prerrogativas gerais dos advogados - à diferença das prerrogativas judiciais (artigo 95 da CRFB) - não tem status constitucional expresso, à exceção da inviolabilidade por atos e manifestações no exercício da profissão (i.e., um aspecto muito específico do rol geral de prerrogativas legais), e, ainda assim, nos limites da lei ordinária (artigo 133 da CRFB);

(ii) promover-se-á preceito penal que assegurará a desigualdade entre iguais, já que não existem "crimes de violação de direitos e prerrogativas profissionais" para outras tantas categorias de profissionais liberais, como médicos, engenheiros, contadores, etc. (e que, não raro, têm também "prerrogativas"; assim, e.g., a do médico, enquanto testemunha, em silenciar quanto ao estado de saúde de seus pacientes - artigo 207 do CPP — , ou a de não servir no tribunal do júri em caso de necessidade de dispensa - artigo 436, par. único, XI, “ $a$ ”, $1^{\text {a }}$ parte, do CPP).

Com efeito, até por uma questão de isonomia (art. 5, caput, da CRFB), a criminalização das condutas violadoras de direitos e prerrogativas profissionais de advogados renderá ensejo a que, no futuro próximo, todas as outras profissões que, em alguma circunstância, detenham direitos especiais ou prerrogativas, venham a reclamar, no Congresso Nacional, a aprovação de leis disciplinando os respectivos crimes de violação. Isso para não falar das prerrogativas republicanas, ínsitas aos membros da Magistratura e do Ministério Público, que detêm inclusive assento constitucional e, todavia, não são objeto de norma penal específica. Tudo a demonstrar que, no programa penal da Constituição de 1988, os direitos e prerrogativas profissionais liberais não admitem tutela penal estrita, por opção sistemática do legislador constituinte.

5. Conflito da conduta criminalizada com a imunidade de exercício profissional de magistrados, membros do ministério público e advogados

Doutro turno, é notório que o ordenamento jurídico estabelece imunidades no exercício profissional a diversos responsáveis pela administração da Justiça, dentre outros.

"In casu", os agentes públicos envolvidos com a aplicação da Justiça têm, pela própria natureza de suas atribuições, imunidade no exercício das mesmas. Do contrário, o membro do Ministério Público que promove a denúncia-crime e acusa alguém da prática de certo ilícito penal veria sobre si, em todo caso, pender a espada de Dâmocles: absolvido o réu (mesmo que por insuficiência de provas), poderia ser processado e julgado por calúnia. $\mathrm{O}$ mesmo raciocínio se aplicaria ao juiz que proferiu a sentença condenatória por crime e que veio a ser reformada por razões quaisquer. Não por outra razão, dispõe 
o art. 41 da Loman que, "salvo os casos de impropriedade ou excesso de linguagem, o magistrado não pode ser punido ou prejudicado pelas opiniões que manifestar ou pelo teor das decisões que proferir". Também não escapariam dessas conseqüências nefastas os advogados, quando assistentes de acusação ou patrocinadores de queixas-crimes, se não lhes aproveitasse a imunidade do art. 133, "in fine”, da CRFB.

Por isso é que o ordenamento jurídico constitucional e legal reconhece a imunidade nestas atividades, inclusive para o advogado, sendo certo que o próprio Estatuto da OAB assegura ao advogado a prerrogativa de não ser processado por crimes contra a honra praticados no exercício da atividade profissional (art. $7^{\circ}, \S 2^{\circ}$ ).

Ocorre que diversos dos direitos e prerrogativas previstos em lei para os advogados são objeto de controvérsia quanto ao seu alcance e forma de aplicação, até mesmo por serem genéricos e insuficientemente descritivos.

Nesse encalço, são recorrentes os casos em que o juiz, o membro do Ministério Público, a autoridade policial, demais autoridades da Administração Pública e, por vezes, parlamentares, especialmente nas comissões de inquérito, interpretam de um ou de outro modo a prerrogativa ou direito invocado pelo advogado.

Acaso aprovada a lei, verificando-se nas instâncias competentes que a interpretação dada pelo juiz, pelo membro do Ministério Público ou pelo parlamentar foi equivocada e que o direito do advogado foi realmente violado, o agente público seria naturalmente processado, podendo ser a final condenado por crime de violação de prerrogativa. Quanto aos crimes contra a honra, p.ex., há fundada doutrina entendendo que a inviolabilidade do art. 133 da CRFB e do art. $7^{\circ}, \S 2^{\circ}$, da Lei n. 8.906/94 não alcança os notórios excessos, absolutamente desnecessários para a defesa profissional dos interesses do cliente (como quando, p.ex., se assacam contra o juiz ou o promotor palavras de baixo calão, em audiência ou em petições). Veja-se, a propósito, o escólio de Fábio Medina Osório $^{7}$ e de Cezar Roberto Bitencourt ${ }^{8}$ (que hoje pertence ao Conselho Federal da OAB); ou, ainda, o próprio teor da ADIn n. 1127-8, em cujo bojo exarou-se liminar suspendendo a eficácia do art. $7^{\circ}, \S 2^{\circ}$, do Estatuto do Advogado, na parte que incluía o desacato entre as hipóteses de imunidade processual dos advogados.

Exemplos ingentes dessa situação (incerteza quanto ao conteúdo das normas que estatuem direitos ou prerrogativas a advogados) dá-se ao ensejo das próprias CPI's, em

\footnotetext{
OSÓRIO, Fábio Medina. A imunidade penal do advogado na Lei 8.906 de 4.7.94 - Estatuto da OAB. Revista Brasileira de Ciências Criminais, São Paulo, n. 9, jan./mar. 1995. In verbis: "O importante é verificar, no caso concreto, se houve necessidade de o advogado ofender o Juiz, o membro do Ministério Público ou a parte contrária. O núcleo da imunidade ai reside: a necessidade das ofensas para o desempenho das funções" ( $\mathrm{p}$. 98 g.n.).

8 BITENCOURT, Cezar Roberto. Tratado de direito penal: parte geral. 6. ed. São Paulo: Saraiva, 2007. v. 1, p. 332-337. In verbis: "Não há que falar em imunidade, no entanto, quando a ofensa for proferida fora do processo ou da discussão da causa, como, por exemplo, no recinto do fórum" (p.335).
} 
que há usualmente sérios limites à participação do advogado, como também ao ensejo do julgamento de certas modalidades de recursos nos tribunais, quando a lei ou os regimentos não prevêem a possibilidade de manifestação de advogados. Não se franqueando a palavra ao patrono, dar-se-á o novel crime?

A se reconhecê-lo, estaríamos diante do odioso "crime de hermenêutica", incriminando-se a conduta do juiz, do delegado de Polícia, do parlamentar ou de qualquer outro que viesse a interpretar a legislação com independência técnica, no exercício de sua função. Apenas por ousar interpretar o sistema em desfavor de um advogado, estar-se-ia sujeito à sanção penal, desde que o entendimento perfilhado não prevalecesse em superior instância... Nada mais absurdo.

6. Inconveniência da política generalizada de criminalização de condutas banais princípio da intervenção pena mínima

Não bastasse, impende recordar que estamos em tempos de Direito Penal mínimo. E é assim notadamente porque o sistema penal contemporâneo revelou-se gravemente ineficaz em relação a seus escopos primeiros (tutela de bens jurídicos de máxima relevância e pacificação social). Disse-o, com muita felicidade, o há pouco finado Alessandro Baratta, com todo o traço humanista que lhe era peculiar (veja-se, a respeito, Criminologia Crítica e Crítica do Direito Penal, passim ${ }^{9}$ ). Nessa linha, a política de criminalização generalizada de condutas jamais é vista com bons olhos pelos estudiosos da ciência criminal; e, já por isso, causou espécie que entidades de renome na seara penal e processual penal, como o Instituto Brasileiro de Ciências Criminais - IBCCrim, que noutros ensejos cerrou fileiras para a crítica à legislação paleorrepressiva, houvesse agora silenciado a respeito do malfadado PL n. 83/2008.

Na verdade, a pretendida "lei de violação de prerrogativas", no afã de dar mais efetividade às garantias e prerrogativas dos advogados, criminaliza condutas banais, de somenos relevância social. No limite, até mesmo questões contratuais relativas a honorários, entre os próprios advogados, poderiam render discussões na órbita criminal, tomando-se por "vítima" aquele que não recebesse o que lhe estaria assegurado pelo ordenamento legal. Da mesma forma (como já ilustrado supra), qualquer modo de tratamento "nãourbano" dispensado ao causídico, como também a omissão de atendimento pessoal ao advogado ou, ainda, a violação mesma de direitos do advogado empregado (não raro pelo próprio advogado-empregador), poderiam, em tese, configurar "crimes".

\footnotetext{
9 BARATTA, Alessandro. Criminologia crítica e crítica do direito penal: introdução à sociologia do direito penal. Trad. Juarez Cirino dos Santos. 3. ed. Rio de Janeiro: Revan/Instituto Carioca de Criminologia, 2002. Veja-se, em especial, o tópico 3 do capítulo XV, sobre A perspectiva da contração e da "superação" do direito penal (p. 205-208).
} 
Como se vê, passa-se da esfera de ilícito administrativo, civil e trabalhista, ou por vezes da mera irregularidade processual, para a esfera punitiva do Direito Penal, com uma fúria que é, "venia concessa", injustificável. Esta política fere a lógica do razoável e o principio da proporcionalidade; fere, pois, o Princípio da Intervenção Mínima, tão caro ao Direito Penal democrático.

Se as normas de direito "não-penal” bem resolvem o contexto conflitivo, com amplo amparo civil, processual e administrativo (para isso, as corregedorias dos Tribunais, das polícias civis e militares e do Ministério Público), não há porque o Estado adotar medidas extremas, tornando "criminosa" toda violação de direito, ainda que verdadeira. $\mathrm{O}$ Direito Penal deve ser reservado para as condutas ilícitas mais graves do meio social, i.e., aquelas que trazem em si afetações qualificadas aos bens jurídicos de máxima relevância jurídico-constitucional (supra, tópico n. 4).

O novo tipo penal, assim genérico e aberto, virá apenas para confundir os operadores na interpretação das normas penais existentes; ou, para mais, servirá para lhes retirar a efetividade social, ante a banalização do manejo criminal em tal seara.

7. Inibição concreta das autoridades na atuação de combate ao crime organizado

O tema da violação de prerrogativas ganhou evidência com os diversos episódios da história nacional recente, amplamente divulgados na mídia, e as sucessivas investigações que envolveram autoridades do Estado, inclusive magistrados, parlamentares, membros do Ministério Público e advogados.

Observa-se que não houve grande reserva ou mobilização de magistrados e de outras autoridades, como categorias organizadas, quando, por ordem judicial, algumas delas sujeitaram-se a medidas de busca e apreensão e similares, colimando-se sempre a garantia da prova em processos envolvendo o crime organizado (assim, p.ex., na Operação Hurricane, durante a qual chegaram a ser devassadas residências e gabinetes de desembargadores). Nem mesmo no Parlamento chegou a haver tamanha indignação contra os procedimentos realizados por determinação judicial, com observância das normas legais e dentro dos parâmetros do Estado de Direito, inclusive em gabinetes de deputados federais.

Houve, todavia, desproporcional clamor das entidades dos advogados, sobretudo em relação a toda e qualquer ordem judicial dirigida à devassa de escritórios ou residências de advogados, a despeito de haver ou-não fundada suspeita de envolvimento em crimes.

Por certo, a criminalização da conduta de "violação de prerrogativa e direito de advogado" tem o mesmo efeito prático da famigerada "lei da mordaça", contra a qual outrora se bateu, aliás veementemente, a própria OAB. Seria uma "lei de peias" para a autoridade judicial, que, caso emitisse ordem judicial fundada em sua convicção de 
verossimilhança, visando à garantia de provas, estaria sempre "ameaçada" de, no futuro, ver-se processada criminalmente, desde que sobreviesse a absolvição do advogado envolvido (mesmo que, insista-se, a absolvição se desse na forma do art. 386, VI, do CPP...).

Com isso, emerge um inexorável efeito colateral dessa lei: o flagrante papel inibitório na ação de autoridades judiciais, membros do Ministério Público e policiais, especialmente nas operações de investigação do crime organizado. E o que é pior: efeito inibitório em prol de uma única categoria profissional, com evidente violação à isonomia constitucional.

Evidentemente, jamais foi esse o propósito da Ordem dos Advogados do Brasil ao eriçar, com tal estridência, a bandeira do PL n. 83/2008. Entretanto, ao cabo e ao fim, uma vez aprovada, tal lei poderá chegar ao extremo de facilitar e estimular a prática do crime organizado, em todas as suas modalidades (narcotráfico, tráfico de armas, lavagem de dinheiro, crimes contra a administração pública, etc.), pela via insuspeita do recurso aos "serviços advocatícios", cooptando-se para tanto advogados desonestos, que contariam com novel escudo normativo para ocultar as suas atividades ilícitas, em flagrante desvio de finalidade da norma.

Dito de outro modo, a inconteste boa-fé da expressiva maioria dos advogados brasileiros, como ainda a do próprio legislador federal que agora faz coro com os desideratos de liberdade institucional daquele ofício, poderiam servir instrumentalmente à tutela do crime, não dos direitos de defesa.

8. Da possibilidade de uso corporativo da legislação penal

Soma-se a todo o dito o risco de que a legislação penal assim editada, consagrando a tutela penal de direitos e prerrogativas profissionais tão específicos, sirva à perseguição corporativa de autoridades e cidadãos comuns.

A esse propósito, merece menção a desconcertante iniciativa da OAB (Secção São Paulo), que remonta ao ano de 2006, de instituir uma "lista negra" em detrimento de tantos quantos tenham sido "condenados", no âmbito interno de sua comissão de prerrogativas, em procedimentos de desagravo e moção de repúdio, pelas mais diversas razões. Assim, p.ex., na relação de novembro de 2006 do assim intitulado "Cadastro das Autoridades que receberam Moção de Repúdio ou Desagravo” (http://www2.oabsp. org.br/asp/comissoes/prerrogativas/ repudio/p06htm, acesso em 23.11.2006), podiam-se encontrar nomes de juízes substitutos e titulares, das mais diversas competências (juízes estaduais, federais e do trabalho); parlamentares (àquela altura, apenas vereadores, mas com larga abrangência: vereadores de São Paulo, Mogi-Mirim, Mogi-Guaçu, Ilha Bela, Cafelância, etc.); autoridades do Poder Executivo (e.g., secretário municipal de administração, diretor-presidente de S.A.A.E.); servidores e auxiliares dos mais variados 
poderes e naipes (peritos e escrivães judiciais, serventuários da Justiça em geral, oficial de promotoria, técnico parlamentar, chefe de seção de benefícios do INSS, etc.); membros do Ministério Público (promotores e procuradores da República) e seus serventuários (oficiais de promotoria); policiais civis e militares (delegados de Polícia, escrivães de Polícia, chefes de investigação e investigadores, soldados e sargentos PM, oficiais policiais militares e até carcereiro); sindicalistas (e.g., diretor de sindicato de trabalhadores domésticos); bancários (gerentes de bancos em geral) e empregados de sindicatos ("funcionário" de sindicato de bancários); conselheiros comunitários (e.g., membro de conselho tutelar municipal); e até mesmo jornalistas (como, p.ex. - e decline-se o nome apenas neste caso, porque maltrata um nome insuspeito, historicamente devotado à defesa dos valores da democracia -, o festejado Elio Gaspari, que lá está já há alguns anos...). Há inclusive menções de identidade equivoca, com potencialidade para lesar terceiros absolutamente alheios aos fatos (como o desagravo em detrimento de "Luís Claudio", "Tenente da PM [...]"). Tal "cadastro" - que até hoje se mantém, a despeito das inúmeras ordens de segurança judicialmente concedidas para supressão de nomes - é francamente publicitado na rede mundial de computadores e por outros diversos meios, com inescusáveis danos ao nome e à imagem de todos os que, justamente ou-não, tenham ensejado, no plano corporativo, desagravos ou moções de repúdio.

Contra os absurdos do "cadastro", já se impetraram inúmeros mandados de segurança, todos concedidos. Cite-se, apenas para constar, aquele impetrado pela Associação dos Magistrados da Justiça do Trabalho da $2^{a}$ Região (Amatra-II), em favor de nada menos que doze juízes do trabalho daquela associação, sob o patrocínio dos advogados Sérgio Lazzarini e Renato Lazzarini, com liminar concedida "in limine litis”; ou, ainda, aquele impetrado conjuntamente pela Associação dos Magistrados da Justiça do Trabalho da $15^{\text {a }}$ Região (Amatra-XV) e pela Associação Paulista de Magistrados (Apamagis), em favor de seus associados (vinte e sete juízes de direito e dois juízes do trabalho), sob o patrocínio do advogado Paulo Rangel do Nascimento, com liminar igualmente concedida em 07.12.2006, pela juíza federal Ritinha A. M. C. Stevenson $\left(20^{\mathrm{a}}\right.$ Vara Cível Federal de São Paulo), ao preciso argumento de que, na interpretação do art. 44, II, do Estatuto da Advocacia, "fica evidente a competência da OAB para a representação, a defesa e a disciplina dos advogados e, não, de qualquer outra categoria profissional, devendo, nesta hipótese, valer-se dos canais e órgãos competentes, na forma da lei" (i.e., corregedorias e tribunais judiciais). E arrematou:

Assim, é de se lamentar que a respeitabilíssima instituição - que se notabilizou na defesa dos direitos humanos, com a manutenção da chama da esperança, nos tenebrosos e longos anos da ditadura - adote o inacreditável comportamento, ora questionado, ao arrepio da lei e da Constituição 
(20 $20^{\text {a }}$ Vara Cível Federal da Capital, autos do Proc. n. MS 2006.61.00.025726-9, fl.160-g.n.).

Vê-se, neste caso, o claro uso corporativo dos expedientes da comissão de prerrogativas, "ao arrepio da lei e da constituição”, nos termos da decisão judicial exarada em São Paulo. E sempre haverá, de fato, esse risco. Pois bem: com a promulgação da "lei de violação de prerrogativas", tomando-se por adequados os juízos daquela comissão na Subsecção de São Paulo, é forçoso antecipar que todas aquelas pessoas - "autoridades" ou-não - estariam, em tese, sujeitas às agruras de um processo penal, por "crime de violação de direitos e prerrogativas de advogados" (afinal, é para repelir esse tipo de conduta que existem, no plano corporativo, os desagravos e as moções de repúdio). Seriam "criminosos", a rigor, todos aqueles há pouco referidos: juízes, promotores, procuradores da República, servidores, policiais militares (inclusive comandantes), policiais civis, peritos, sindicalistas, gerentes de bancos, conselheiros comunitários, autoridades políticas municipais e inclusive parlamentares.

Legislação penal que serve a fins puramente corporativos não se coaduna com o Estado Democrático de Direito. Tampouco com a República porquanto, afinal, ao interesse corporativo (conquanto tenda a ser, inclusive, um interesse socialmente legítimo) não se pode reduzir, em absoluto, o interesse público primário; e somente a esse deve ser emprestada a genuína tutela penal. Do contrário, instaurar-se-á um regime pérfido de instrumentalização corporativa das leis penais que, no final, não aproveitará a quem quer que seja; nem mesmo aos advogados (e tanto menos aos cidadãos em geral).

9. Da suficiência tuitiva da legislação penal em vigor

Acresça-se, por fim, que sequer é necessária a pretendida tutela penal de direitos e prerrogativas profissionais de advogados, já que existem, no sistema penal em vigor, dispositivos bastantes para a prevenção e a repressão penal de abusos por parte de autoridades e agentes públicos. Dispositivos que - diga-se - têm conteúdo claro, gozam de tradição na Jurisprudência brasileira, atendem ao princípio da proporcionalidade penal e não promovem persecução de bagatelas, atendo-se aos casos realmente graves de violação de prerrogativas.

Assim, por exemplo, nas hipóteses em que o parlamentar, o magistrado, o membro do Ministério Público ou o policial ordenarem ou executarem medida privativa de liberdade em desconformidade com a lei ou com abuso de poder, terá praticando, em tese, o crime de exercício arbitrário ou abuso de poder, sujeitando-se às penas do art. 350, caput, do Código Penal (detenção, de um mês a um ano). Vale para todas as ordens de prisão ilegais dimanadas e/ou executadas contra advogados ou qualquer do povo. Quanto às buscas e apreensões ilegais em escritórios de Advocacia, o sistema penal em vigor já 
provê, do mesmo modo, a tutela penal: a conduta de efetuar, com abuso de poder, qualquer diligência (inclusive as judiciais) está, há não pouco tempo, prevista na lei penal brasileira, como tipo penal equiparado ao do crime de exercício arbitrário ou abuso de poder (art. 350, par. único, IV, do CP), com as mesmas penas a ele cominado. E há, para mais, a norma penal do art. 150 do $\mathrm{CP}$ (violação de domicílio), igualmente aplicável à hipótese, qual soldado de reserva (princípio da subsidiariedade implícita), considerando-se o teor do seu parágrafo $4^{\circ}$, inciso III.

E não é só. Se a autoridade judiciária, ministerial ou policial for além, praticando violência em detrimento de advogado ou qualquer do povo, responderá pelo crime de violência arbitrária ("no exercício da função ou a pretexto de exercê-la"), nos precisos termos do art. 322 do $\mathrm{CP}$, com penas que vão de seis meses a três anos de detenção (mais do que se pretende no PLC n. 83/2008), também sem prejuízo da pena correspondente à violência (tal como se pretende no PLC n. 83/2008).

Por fim, ainda que assim não fosse (e, nesse diapasão, viceja a respeito alguma discussão doutrinária quanto à convivência dos tipos ou a revogação da "lex praevia"), sobreveio, em 09.12.1965, a Lei n. 4.898, que "regula o Direito de Representação e o processo de Responsabilidade Administrativa Civil e Penal, nos casos de abuso de autoridade". Lê-se ali, entre outras coisas, que são condutas criminosas, punidas com detenção de dez dias a seis meses, as seguintes (atente-se para os nossos grifos):

Artigo $3^{\circ}$ - Constitui abuso de autoridade qualquer atentado:

a) à liberdade de locomoção;

b) à inviolabilidade do domicílio;

c) ao sigilo da correspondência;

d) à liberdade de consciência e de crença;

e) ao livre exercício do culto religioso;

f) à liberdade de associação;

g) aos direitos e garantias legais assegurados ao exercício do voto;

h) ao direito de reunião;

i) à incolumidade física do indivíduo;

j) aos direitos e garantias legais assegurados ao exercício profissional. [incluído pela Lei n. 6.657,de 5.6.79]

“Artigo $4^{\circ}$ - Constitui também abuso de autoridade:

a) ordenar ou executar medida privativa da liberdade individual, sem as formalidades legais ou com abuso de poder;

b) submeter pessoa sob sua guarda ou custódia a vexame ou a constrangimento não autorizado em lei;

c) deixar de comunicar, imediatamente, ao juiz competente a prisão ou detenção de qualquer pessoa;

d) deixar o Juiz de ordenar o relaxamento de prisão ou detenção ilegal que lhe seja comunicada; 
e) levar à prisão e nela deter quem quer que se proponha a prestar fiança, permitida em lei;

f) cobrar o carcereiro ou agente de autoridade policial carceragem, custas, emolumentos ou qualquer outra despesa, desde que a cobrança não tenha apoio em lei, quer quanto à espécie quer quanto ao seu valor;

g) recusar o carcereiro ou agente de autoridade policial recibo de importância recebida a título de carceragem, custas, emolumentos ou de qualquer outra despesa;

h) $\underline{o}$ ato lesivo da honra ou do patrimônio de pessoa natural ou jurídica, quando praticado com abuso ou desvio de poder ou sem competência legal;

i) prolongar a execução de prisão temporária, de pena ou de medida de segurança, deixando de expedir em tempo oportuno ou de cumprir imediatamente ordem de liberdade. [Incluído pela Lei n. 7.960, de 21.12.1989]

Aí estão distribuídas praticamente todas as condutas contra as quais quer se insurgir a Ordem dos Advogados do Brasil, ao patrocinar a aprovação do PLC n. 83/2008. Ressalte-se, em especial, a alínea “j” do art. $3^{\circ}$, que foi inserida em 1979 por gestões, entre outras, da própria $\mathrm{OAB}$, e que serve justamente à prevenção e repressão das condutas de autoridades que violam, concretamente, os direitos e as garantias legais profissionais que, no caso da Advocacia, dimanam hoje da Lei n. 8.906/94, "in totum" (e não apenas de seu art. $7^{\circ}$, como pretende dispor o PLC n. 83/2008). Mesmo essa previsão, pela sua abertura, é de constitucionalidade duvidosa (supra, tópico n. 3); mas, para o bem ou para o mal, a norma já existe e está em vigor, sem qualquer declaração judicial de inconstitucionalidade ou não-recepção que seja vinculante "erga omnes". Logo, a "nova” norma - que, no fundo, vai simplesmente repositivar toda essa matéria, de modo ainda mais genérico e pantanoso, nos lindes da mais gritante inconstitucionalidade - não tem qualquer razão de ser, social ou politicamente. A tutela penal das "prerrogativas profissionais” já existe (e para todos, como deve ser; não apenas para advogados). Basta fazê-la valer, "si et quando" necessária.

\section{Conclusão}

Por todos estes fundamentos, a par de outros tantos que vêm sendo esgrimidos pelas associações de juízes e membros do Ministério Público, é que a Comissão Legislativa da Anamatra pugnou, em duas ocasiões, pela não-aprovação do projeto em testilha (agora consubstanciado no PLC n. 83 do Senado Federal). São baldrames que expressam, acima de tudo, nossa convicção técnica. E, nisso, buscou-se a maior isenção possível.

Concriada para o mundo jurídico-positivo, a novel legislação padecerá, a um tempo, dos vícios da inconstitucionalidade e da inconveniência político-criminal. Ferir-se-á o princípio da taxatividade penal. Legislar-se-á fora dos marcos seguros do 
Programa Penal da Constituição. Dar-se-á criminalização a condutas banais. Engendrar-seá instrumento que inibe a atuação dos agentes públicos no combates ao crime organizado. Criminalizar-se-á em excesso, contrariando a tendência universal do Direito Penal mínimo. As salvaguardas corporativas, s.m.j., não podem chegar a tanto.

Como manifestamos em recente artigo de mídia impressa, "os advogados têm, é certo, prerrogativas inalienáveis. E é bom que as tenham. Mas não às custas das liberdades públicas; nem tampouco a reboque de um Direito Penal do insólito". Que o percebam a tempo.

São Paulo, novembro de 2007.

\section{Referências}

BARATTA, Alessandro. Criminologia crítica e crítica do direito penal: introdução à Sociologia do Direito Penal. Tradução de Juarez Cirino dos Santos. 3. ed. Rio de Janeiro: Revan / Instituto Carioca de Criminologia, 2002.

BITENCOURT, Cezar Roberto. Tratado de Direito Penal: parte geral. 6. ed. São Paulo: Saraiva, 2007. v. I.

FELICIANO, Guilherme Guimarães. Teoria da imputação objetiva no direito penal ambiental. São Paulo: LTr, 2005.

OSÓRIO, Fábio Medina. A imunidade penal do advogado na Lei n. 8.906 de 4.7.94: Estatuto da OAB. Revista Brasileira de Ciências Criminais, São Paulo, n. 9, jan./mar. 1995.

QUEIROZ, Paulo de Souza. Direito Penal: introdução crítica. São Paulo: Saraiva, 2001.

RODRÍGUEZ-ARIAS, Antonio Mateos. Derecho penal y protección del medio ambiente. Madrid: Colex, 1995.

ROXIN, Claus. Derecho Penal: parte general (Fundamentos. La estructura de la teoria del delito). Trad. Diego-Manuel Luzón Peña, Javier de Vicente Remesal. Madrid: Civitas, 1997. t. 1.

ZAFFARONI, Eugénio Raul; BATISTA, Nilo. Direito penal brasileiro. 2. ed. Rio de Janeiro: Revan, 2003. v. 1 . 